\title{
ANALISIS PERLAKUAN AKUNTANSI TERHADAP PENERIMAAN NEGARA BUKAN PAJAK (PNBP) ATAS JASA LAYANAN IPTEK NUKLIR
}

\author{
SRI AGUSTINI \\ Prodi Akuntansi S1, Fakultas Ekonomi, Universitas Pamulang, Banten \\ *Email: agustin@batan.go.id
}

\begin{abstract}
The mechanism for managing PNBP services in BATAN is guided by Law (Law) Number 20 of 2017 concerning PNBP, Government Regulation (PP) Number 29 of 2011 concerning Types and Rates of PNBP Types that Apply to the National Nuclear Energy Agency, Government Regulation (PP) Number 71 of 2010 concerning Government Accounting Standards (SAP), Technical Bulletin of Government Accounting Standards Number 23 concerning Accounting for Non-Tax Revenue Collection, and Regulation of the Minister of Finance of the Republic of Indonesia (PMK-RI) Number 152 / PMK.02 / 2014 concerning Instructions for the Compilation of PNBP of the State Ministries / Institutions implemented by 16 work units in BATAN for 15 types of Nuclear Science and Technology services. In order to meet the needs of the community for goods / services in the nuclear sector, BATAN provides services in the field of nuclear science and technology (science and technology), one of which is carried out through an application system. In line with bureaucratic reforms which have an impact on changes in governance in various fields, the regulation of PNBP. Law Number 20 Year 1997 concerning PNBP only contains PNBP groups and rules in general, and their implementation is regulated in detail through PP. However, the preparation of legislation requires a long time, while the implementation of PNBP must continue to run. In implementing PNBP, BATAN is increasingly demanded to provide services that are fast, easy, practical and transparent. Service customers do not have to come to the intended work unit to complete administration. With online-based administration all communication with customers can be done both ways. This study uses descriptive analysis, showing the largest percentage of PNBP service use in BATAN out of 15 types of Nuclear Science and Technology services in 2017 conducted by the PSTBM Work Unit (99.64\%) and the smallest percentage of use by the PTBGN Work Unit (5.88\%) (able seen in the results of the discussion on pages 10-14).
\end{abstract}

Keywords: PNBP, Measurement,Acceptance, Use, Nuclear Science and Technology Services. 


\section{PENDAHULUAN}

\section{Latar Belakang Penelitian}

Dalam rangka memenuhi kebutuhan masyarakat terhadap barang/jasa di bidang ketenaganukliran, BATAN memberikan jasa layanan di bidang ilmu pengetahuan dan teknologi (iptek) nuklir yang salah satunya dilakukan melalui mekanisme PNBP. Pajak yang berlaku selama ini meliputi berbagai ragam dan tingkatan peraturan sehingga belum sepenuhnya mencerminkan kepastian hukum. Banyak dan beragamnya bentuk pengaturan juga mengakibatkan kekurangtertiban dan kerumitan dalam pengelolaan Penerimaan Negara Bukan Pajak(Undang-undang Nomor 20 Tahun 1997 1997).

Penerapan PNBP tidak diberlakukan untuk pelayanan antar unit kerja di BATAN, sesuai dengan Surat Edaran Sekretaris Utama (Settama) BATAN Nomor 2 Tahun 2017. Pengenaan tarif PNBP antar unit kerja akan menimbulkan sistem tata kelola yang tidak efisien terhadap pengelolaan PNBP, anggaran dan belanja BATAN. Dalam rangka efisiensi dan efektifitas pelaksanaan anggaran maka layanan antar unit kerja di BATAN dibebaskan dari pengenaan tarif PNBP. Hal ini juga sejalan dengan kebijakan pimpinan terkait BATAN incorporated. Pengelolaan layanan antar unit kerja tersebut juga telah mendapat persetujuan dari Kementerian Keuangan RI melalui surat Nomor S94/MK.2/2016 tanggal 13 Juni 2016. Adapun jenis layanan PNBP yang berlaku pada BATAN terdiri dari 15 jenis jasa layanan, yaitu:

1 Jasa Kalibrasi

Layanan jasa kalibrasi dosimeter, keluaran radiasi, tekanan, dan besaran volume.

2 Jasa Sertifikasi meliputi: kalibrasi survey meter, pocket dosimeter, sumber standar, curiemeter, besaran suhu, besaran Layanan jasa sertifikasi meliputi: sertifikasi bebas radiasi komoditi ekspor/impor (kandungan radionuklida), personal, dan sistem manajemen mutu nuklir.

3 Jasa Analisis Pemantauan Radiasi Perorangan dan Daerah Kerja

Layanan jasa analisis pemantauan radiasi perorangan dan daerah kerja meliputi: analisis film monitor, TLD monitor, tingkat radiasi daerah kerja, tingkat kontaminasi benda uji, dan tingkat kontaminasi zat radioaktif.

4 Jasa Iradiasi

Layanan jasa iradiasi meliputi: jasa iradiasi menggunakan berkas lektron, gamma irradiator, gamma reaktor, jasa iradiasi neutron reaktor, jasa iradiasi batu topaz, pelapisan permukaan menggunakan mesin berkas elektron dan iradiasi ultraviolet dan uji sifat cairan. Layanan jasa iradiasi dapat dilakukan untuk meningkatkan nilai batu mulia, pengawetan bahan pangan, pelapisan permukaan kayu, sterilisasi peralatan medis, dll.

5 Jasa Pengelolaan Limbah Radioaktif

Layanan jasa pengelolaan limbah radioaktif meliputi: limbah cair, semi cair, dan padat, sumber radioaktif bekas, dan bahan bakar nuklir bekas.

6 Jasa Eksplorasi Bahan Galian dengan Teknologi Nuklir

Layanan jasa ini meliputi: eksplorasi bahan galian/prospeksi, penyelidikan geofisika mineral, pemetaan topografi, pemboran inti, pengukuran diagrafi nuklir, jasa pemanfaatan peralatan dan penyelidikan geohidrologi. Layanan jasa eksplorasi khususnya penyelidikan geohidrologi dapat dimanfaatkan untuk pelacakan air tanah dalam di daerah sulit air. 
7 Jasa Pengerjaan dan Uji Mekanik

Layanan jasa uji mekanik meliputi: uji tarik pelat, uji tarik bulat, uji kekerasan, uji impak, uji lelah, uji mulur, uji ketahanan permukaan, uji kekasaran permukaan, implantasi ion, dan nitridasi ion/plasma.

8 Jasa Penyiapan Sampel dan Analisis

Layanan jasa penyiapan sampel dan analisis meliputi: analisis struktur mikro, uji ketahanan sifat kimia larutan, analisis korosi, analisis termal, analisis komposisi, analisis mikro biologi, analisis klinik, analisis pemodelan, analisis sampel untuk industri, analisis partikulat udara, analisis partikel, analisis pengujian produk, analisis kimia dan lainnya.

9 Jasa Konsultasi

Layanan jasa konsultasi: konsultasi dan verifikasi, serta konsultasi teknik penelusuran dan penyelesaian masalah di dalam industri.

10 Jasa Pelayanan Teknis Uji Tidak Merusak

Layanan jasa uji tidak merusak meliputi: uji hidrostatik, termografi inframerah, ultrasonic, analisis paduan, eddy current, uji penetran, radiografi Cobalt-60, radiografi sinar $\mathrm{X}$ dan gamma, interpretasi film radiografi, uji kesesuaian pesawat sinar $\mathrm{X}$ radiologi diagnostik dan intervensional, radiografi beton, dan magnetic partikel.

11 Jasa Keahlian Ketenaganukliran

Layanan jasa keahlian ketenaganukliran meliputi: konsultasi ahli, konsultasi pelaksana, dan jasa perbantuan tenaga ahli bidang geologi.

12 Penjualan Produk Teknologi Nuklir

Produk teknologi nuklir yang dijual yaitu: produk radiofarmaka (Cardioscan, Renocystan, Hepatostan, Pyrostan Sn, Sulfostan, Osteostan, Pentostan, Macrostan, Tibistan, Neurostan, Ciprostan, Renomercapstan), air bebas mineral, nitrogen cair, khitin dan oligokhitosan, lateks alam iradiasi, standar U3O8, standar Thorium Oksida, standar UO2, produk kesehatan dan jaringan biologi (freeze dried amniotic membrane, air-dried amniotic membrane, bone allograft/xengraft, femoral strut, lambone, bone ocular spherical implant, periosteum membrane, percardium membrane, bone spongy cube, bone cortico cancellous, cranium graft), benih padi, benih kedelai, 153Sm-EDTMP, MIBG I-131, Na-I-125, seed brakiterapi, generator Tc-99m dan dry ice.

13 Jasa Pendidikan dan Pelatihan

Layanan jasa pendidikan dan pelatihan meliputi: diklat radiografi, diklat keselamatan radiasi pengion bagi calon petugas proteksi radiasi industri, dan diklat proteksi radiasi bagi pekerja radiasi.

14 Jasa Sewa Peralatan Teknologi Nuklir

Peralatan teknologi nuklir yang disewakan yaitu: renograf, tyroid uptake, pesawat sinar $\mathrm{x}$, pemanfaatan kanal hubung, microwave digestion, neraca mikro, freeze dryer, otoklaf, oven, laminar air flow, clean room, tungku pemanas, dan tungku oksidasi.

15 Jasa Pendidikan pada Sekolah Tinggi Teknologi Nuklir

BATAN menyelenggarakan layanan jasa pendidikan tinggi melalui Sekolah Tinggi Teknologi Nuklir (STTN) yang berlokasi di Yogyakarta dengan tiga program studi 
diploma IV yaitu Elektronika Instrumentasi, Elektro Mekanika dan Teknokimia Nuklir.

16 Jasa Pelaksanaan Uji Profisiensi

Layanan jasa pelaksanaan uji profisiensi meliputi: uji profisiensi untuk komoditi sampel pangan, komoditi sampel lingkungan, komoditi sampel biologi, serta komoditi sampel obat dan suplemen.

17 Jasa Pelayanan Penelitian dan Pengembangan di Bidang Ilmu Pengetahuan dan Teknologi Nuklir yang berasal dari kerja sama dengan pihak lain. Layanan jasa penelitian dan pengembangan iptek nuklir yang tidak tercantum dalam

Peraturan Pemerintah Nomor 29 Tahun 2011 tentang Jenis dan Tarif atas Jenis PNBP yang Berlaku pada BATAN dapat dilakukan melalui mekanisme perjanjian kerja sama dengan perseorangan/perusahaan/instansi pemerintah lainnya dengan rincian biaya yang telah disepakati dan mengacu pada standar biaya yang berlaku.

Layanan jasa iptek nuklir untuk masyarakat adalah layanan yang diberikan oleh BATAN kepada masyarakat, baik perorangan maupun lembaga/instansi dengan memanfaatkan fasilitas-fasilitas yang dimiliki oleh BATAN yang berada di Jakarta (Kuningan dan Lebak Bulus), Serpong-Tangerang, Bandung, dan Yogyakarta.

\section{Perumusan Masalah}

Berdasarkan judul dan latar belakang penelitian yang telah penulis paparkan sebelumnya, maka dapat dirumuskan sebagai berikut:

1). Bagaimana menganalisis perlakuan akuntansi terhadap PNBP atas layanan jasa iptek nuklir di BATAN?

2). Bagaimana mengetahui kelemahan atau kekurangan dari pengelolaan PNBP terhadap unit kerja di BATAN dan sebagai bahan masukan/rekomendasi pengambil kebijakan dalam rangka perbaikan kinerja BATAN ke depan.

\section{Tujuan dan Manfaat}

Untuk mengetahui Analisis perlakuan akuntansi terhadap PNBP atas layanan jasa iptek nuklir di BATAN, antara lain:

1) Untuk mengukur dan menganalisis perlakuan akuntansi PNBP atas layanan jasa iptek nuklir di BATAN

2) Untuk mengetahui kelemahan atau kekurangan dari pengelolaan PNBP terhadap unit kerja di BATAN dan sebagai bahan masukan/rekomendasi pengambil kebijakan dalam rangka perbaikan kinerja BATAN ke depan.

\section{TINJAUAN PUSTAKA}

Demi untuk mencapai kesejahteraan umum dan mencerdaskan kehidupan bangsa sebagaimana tercantum pada alinea ke 4 pembukaan Undang-Undang Dasar 1945 maka pemerintah perlu adanya rencana kerja yang diperhitungkan dengan keuangan yang disusun secara sistematis, dimana mencakup rencana penerimaan dan rencana pengeluaran untuk satu tahun anggaran yang berfungsi untuk mengelola suatu pemerintahan yang efektif dalam mencapai tujuannya (Rima P.A Walelang 2017). 
Sumber-sumber penerimaan Negara Indonesia berasal dari berbagai sektor, dimana semua hasil penerimaan tersebut digunakan oleh pemerintah dalam rangka penyelenggaraan pemerintahan dan pelaksanaan pembangunan nasional yang merata dan berkesinambungan. Untuk membiayai penyelenggaraan pemerintahan dan pembangunan nasional tersebut terdapat 2 (dua) sumber penerimaan utama, yaitu penerimaan perpajakan dan penerimaan negara bukan pajak (PNBP) (Dinarjito 2017).

Penerimaan Negara di luar penerimaan perpajakan. Penerimaan perpajakan meliputi penerimaan yang berasal dari Pajak Penghasilan, Pajak Pertambahan Nilai dan Pajak Penjualan atas Barang Mewah, Bea Masuk, Cukai Pajak Bumi dan Bangunan, Bea Meterai, Bea Perolehan Hak atas Tanah dan Bangunan, dan penerimaan lainnya yang diatur dengan peraturan perundang-undangan di bidang perpajakan (Undang-undang Nomor 20 Tahun 1997 1997). Sehubungan dengan adanya perubahan jenis dan tarif atas jenis Penerimaan Negara Bukan Pajak pada Badan Tenaga Nuklir Nasional dalam upaya mengoptimalkan Penerimaan Negara Bukan Pajak guna menunjang Pembangunan Nasional, perlu mengganti Peraturan Pemerintah Nomor 77 Tahun 2008 tentang Jenis dan Tarif atas Jenis Penerimaan Negara Bukan Pajak yang Berlaku pada Badan Tenaga Nuklir Nasional (Peraturan Pemeritah Republik Indonesia Nomor 29 Tahun 2011 2011).

Tarif atas jenis PNBP ditetapkan dengan memperhatikan dampak pengenaan terhadap masyarakat dan kegiatan usahanya, biaya penyelenggaraan kegiatan Pemerintah sehubungan dengan PNBP yang bersangkutan, dan aspek keadilan dalam pengenaan beban kepada masyarakat. Pengelolaan kegiatan PNBP di BATAN meliputi 15 jenis kegiatan layanan PNBP yang dilakukan 16 Unit Kerja di BATAN. Kegiatan PNBP di BATAN dikelola oleh Biro Perencanaan mempunyai tugas menyiapkan bahan koordinasi PNBP.

\section{Program dan Kegiatan Pengelolaan Layanan PNBP di BATAN}

Program dan Kegiatan Pengelolaan PNBP di BATAN disusun untuk memudahkan pengguna yakni Unit Kerja di lingkungan BATAN, dapat dilihat pada gambar berikut ini:

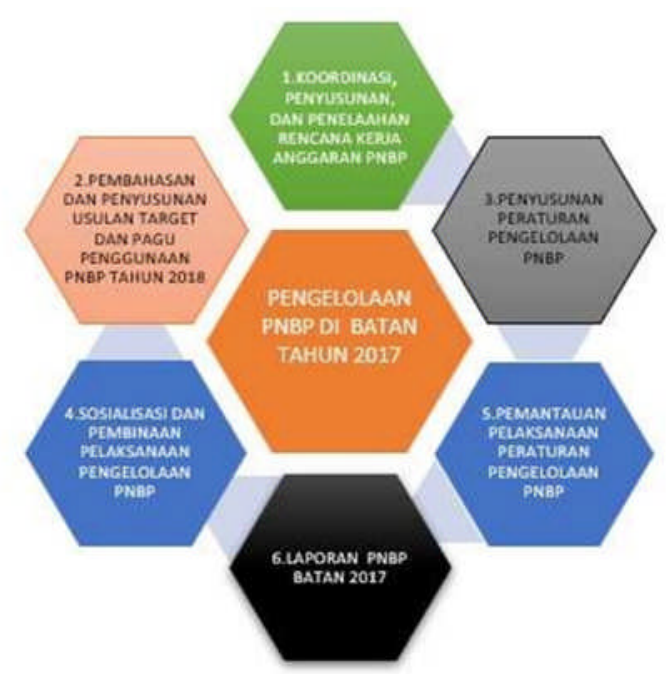

Gambar 1. Program dan Kegiatan Pengelolaan PNBP BATAN 2017 


\section{Basis Akuntansi}

Laporan Keuangan BATAN menerapkan basis akrual dalam penyusunan dan penyajian Neraca, Laporan Operasional, dan Laporan Perubahan Ekuitas serta basis kas untuk penyusunan dan penyajian Laporan Realisasi Anggaran. Peristiwa atau transaksi lain yang menimbulkan hak pemerintah untuk menagih, antara lain timbul dari perikatan misalnya transkasi pemberian pinjaman oleh pemerintah, jual beli atau pertukaran, kemitraan, dan pemberiaan jasa-jasa yang telah dilakukan pemerintah. Peristiwa lainnya adalah berkaitan dengan timbulnya hak tagih dalam hal terjadi kerugian Negara maupun putusan pengadilan. Hal ini diatur dalam Buletin Teknis Standar Akuntansi Pemerintahaan Nomor 16 tentang Akuntansi Piutang Berbasis Akrual

\section{Kebijakan Akuntansi}

Penyusunan dan penyajian Laporan Keuangan Tahun 2017 telah mengacu pada Peraturan Pemerintah Nomor 71 Tahun 2010 tentang Standar Akuntansi Pemerintah (SAP), dan Buletin Teknis Nomor 23 SAP tentang Akuntansi Pendapatan Non Perpajakan. Kebijakan akuntansi merupakan prinsip-prinsip, dasar-dasar, konvensikonvensi, aturan-aturan, dan praktik-praktik spesifik yang dipilih oleh suatu entitas pelaporan dalam penyusunan dan penyajian laporan keuangan. Kebijakan akuntansi yang diterapkan dalam laporan keuangan ini adalah merupakan kebijakan yang ditetapkan BATAN. Disamping itu, dalam penyusunannya telah diterapkan kaidah-kaidah pengelolaan keuangan yang sehat di lingkungan pemerintahan khususnya di BATAN.

\section{Pengukuran Layanan PNBP}

Pengukuran adalah proses penetapan nilai uang untuk mengakui dan memasukkan setiap pos dalam laporan keuangan. Dasar pengukuran yang diterapkan Laporan Keuangan BATAN dalam penyusunan dan penyajian Laporan Keuangan adalah dengan menggunakan nilai perolehan historis. Aset dicatat sebesar pengeluaran/penggunaan sumber daya ekonomi atau sebesar nilai wajar dari imbalan yang diberikan untuk memperoleh aset tersebut. Kewajiban dicatat sebesar nilai wajar sumber daya ekonomi yang digunakan pemerintah untuk memenuhi kewajiban yang bersangkutan. Pengukuran pos-pos laporan keuangan menggunakan mata uang rupiah. Transaksi yang menggunakan mata uang asing dikonversi terlebih dahulu dan dinyatakan dalam mata uang rupiah. Pengukuran layanan PNBP di BATAN menggunakan rumus sebagai berikut:

\section{TARIF JENIS LAYANAN PNBP X LAYANAN PNBP}

\section{METODOLOGI}

\section{Tempat Penelitian}

Penelitian ini adalah penelitian deskriptif menggunakan interpretasi analisis data kualitatif dengan desain cross sectional (Iriviranty 2014). Teknik pengumpulan data dan informasi dalam penelitian ini menggunakan data sekunder yang diperoleh dari literatur dan dokumen BATAN. Data yang diperlukan untuk menjawab tujuan penelitian adalah 
data layanan Jasa Iptek Nuklir. Lokasi penelitian dilakukan di Biro Perencanaan, Kantor Pusat BATAN, Jakarta. Waktu yang diperlukan untuk menyelesaikan penelitian adalah 3 Bulan.

\section{Analisis PNBP Jasa Layanan Iptek Nuklir}

Pengolahan data dilakukan dengan menginput data penerimaan dan penggunaan PNBP Jasa Layanan Iptek Nuklir pada aplikasi Microsoft Olffice Excel kemudian mengolah dan menganalisisnya. Rekapitulasi data PNBP Jasa Layanan Iptek Nuklir beserta analisisnya dilakukan dengan memasukkan data sekunder yang berasal dari unit kerja dan berdasarkan data Laporan PNBP BATAN. Data-data tersebut kemudian diolah dan disajikan secara grafis dan dianalisis.

\section{HASIL DAN PEMBAHASAN}

\section{Analisis Deskriptif Jasa Layanan PNBP Iptek Nuklir di BATAN}

Objek penelitian ini adalah 18 layanan PNBP dari 16 unit kerja di BATAN. Dari hasil pengolahan data laporan keuangan per 31 Desember 2017. Secara rinci target dan realisasi penerimaan 18 layanan PNBP dapat dijelaskan tabel dan grafik berikut ini:

Tabel 1. Target dan Penerimaan PNBP BATAN 2017

\begin{tabular}{|c|c|c|c|c|c|c|}
\hline No & $\begin{array}{l}\text { Nama Unit } \\
\text { Kerja }\end{array}$ & Target & Fungsional & Umum & $\begin{array}{c}\% \\
\text { Penerimaan } \\
\text { Fungsional }\end{array}$ & $\begin{array}{c}\% \\
\text { Penerimaan }\end{array}$ \\
\hline 1. & PAIR & 2.960 .090 .000 & 2.560 .737 .400 & 162.207 .227 & 86,51 & 91.99 \\
\hline 2. & PTBGN & 744.500 .000 & 42.376 .500 & 30.924 .484 & 5,69 & 9,85 \\
\hline 3. & KANPUS & 221.650 .000 & 0 & 461.449 .821 & 0 & 208,19 \\
\hline 4. & PSTNT & 472.825 .000 & 402.150 .000 & 33.754 .279 & 85,05 & 92,19 \\
\hline 5. & PSTA & 151.535 .000 & 138.552 .000 & 393.244 .296 & 91,43 & 350,94 \\
\hline 6 & PTKMR & 7.000 .000 .000 & 7.866 .309 .000 & 229.439 .807 & 112,38 & 115,65 \\
\hline 7. & PPIKSN & 302.500 .000 & 182.520 .000 & 167.835 .946 & 60,34 & 115,82 \\
\hline 8. & PUSDIKLAT & 4.180 .025 .000 & 3.414 .981 .000 & 17.902 .414 & 81,70 & 82,13 \\
\hline 9. & PRSG & 3.237 .500 .000 & 2.396 .453 .250 & 70.030 .539 & 74,02 & 76,18 \\
\hline 10. & PTBBN & 606.375 .000 & 432.719 .000 & 201.236 .290 & 71,36 & 104,55 \\
\hline 11. & PSTBM & 264.980 .000 & 284.785 .000 & 25.528 .404 & 107,47 & 117,11 \\
\hline 12. & PRFN & 82.750 .000 & 16.455 .000 & 35.113 .978 & 19,89 & 62,32 \\
\hline 13. & PTRR & 275.000 .000 & 258.140 .000 & 84.006 .065 & 93,87 & 124,42 \\
\hline 14. & PTLR & 1.443 .804 .000 & 330.305 .500 & 199.525 .477 & 22,88 & 36,70 \\
\hline 15. & PTRKN & 100.000 .000 & 0 & 42.066 .431 & 0 & 42,07 \\
\hline 16. & STTN & 3.006 .900 .000 & 2.420 .580 .000 & 56.377 .621 & 80,50 & 82,38 \\
\hline 17. & PKSEN & 0 & 0 & 48.618 .663 & 0 & 0 \\
\hline 18. & INSPEKTORAT & 0 & 0 & 1.219 .953 & 0 & 0 \\
\hline 19. & PDK & 0 & 0 & 66.001 .933 & 0 & 0 \\
\hline 20. & PSMN & 220.000 .000 & 123.575 .000 & 25.116 .541 & 56,17 & 67,59 \\
\hline & TOTAL & 25.270 .434 .000 & 20.870 .638 .650 & 2.351 .600 .169 & - & - \\
\hline
\end{tabular}

Sumber Data : Laporan PNBP BATAN Tahun 2017 


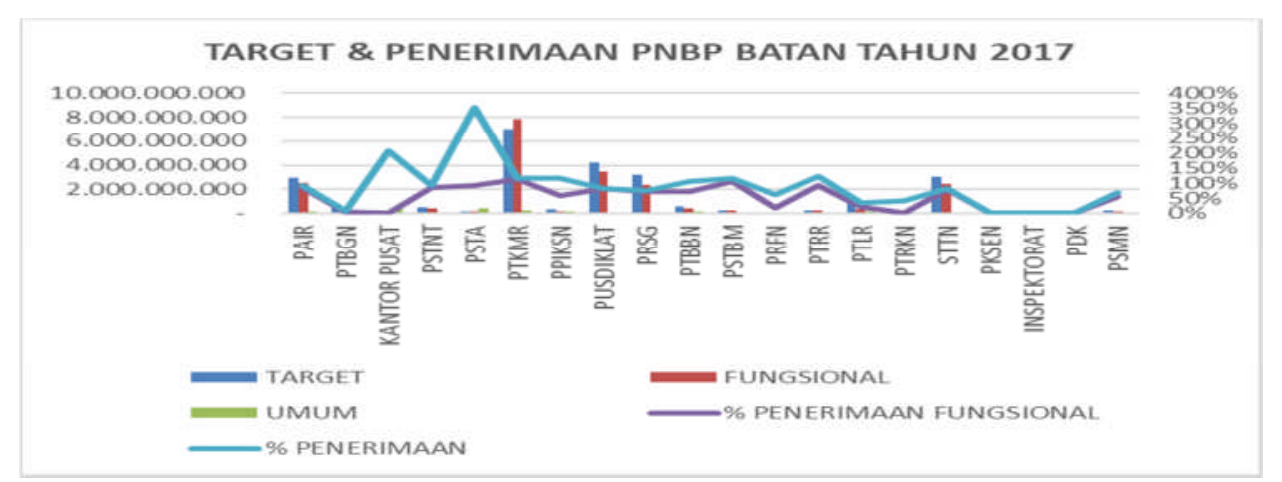

Gambar Grafik 2. Target \& Penerimaan PNBP BATAN 2017

Hasil analisis menunjukkan bahwa realisasi penerimaan PNBP BATAN 2017 sebesar Rp23.222.238.819,00 (91,89\%) dari target penerimaan Rp25.270.434.000,00 dengan penerimaan fungsional sebesar Rp20.870.638.650,00 (83,60\%)

Rp.2.351.600.169,00 (91,89\%). Penerimaan fungsional tahun 2017 mengalami penurunan yang cukup besar jika dibandingkan dengan penerimaan fungsional tahun 2016 sebesar Rp23.723.660.334,00. Dari 16 satker pengelola PNBP, hanya 2 unit kerja yang mencapai target penerimaan yaitu PTKMR sebesar Rp7.870.309.000,00 dari target Rp7.000.000.000,00 dan PSTBM sebesar Rp284.785.000,00 dari target Rp264.980.000,00. Peningkatan penerimaan fungsional disebabkan oleh peningkatan pendapatan dari penjualan, kontribusi manajemen BMN dan Badan Usaha, peningkatan pendapatan pendidikan, budaya, penelitian dan teknologi, peningkatan pendapatan dari layanan lain, peningkatan pendapatan bunga, peningkatan manajemen rekening bank. Persentase penerimaan fungsional di bawah 90\% terjadi di PTBGN (5,69\%), PRFN (19,89\%), PTLR (22,88\%), PSMN (56,17\%), PPIKSN (60,34\%), PTBBN (71,36\%), PRSG $(74,02 \%))$, STTN $(80,50 \%)$ dan PUSDIKLAT $(81,70 \%)$. Penurunan signifikan dalam penerimaan fungsional di BATAN disebabkan oleh penurunan PTLR, PRSG, PUSDIKLAT, PTBGN, STTN, dan PAIR. Penurunan penerimaan fungsional disebabkan oleh adanya piutang yang belum dibayar di unit kerja PRSG, keberadaan Surat Edaran Sekretaris Utama No.2 Tahun 2017 tanggal 8 Juni 2017 tentang Pembebasan Pembayaran Layanan antar Unit Kerja di BATAN, peralatan yang digunakan atau disewa untuk layanan yang mengalami kerusakan parah dan perbaikan membutuhkan waktu lama untuk unit kerja PSTNT dan PSTA, mengurangi permintaan untuk layanan analisis dan pengujian dari pelanggan, dan mengurangi permintaan bantuan SDM dari PT Industri Nuklir Nasional (Persero) di PTBBN unit kerja.

Tabel 2. Realisasi Penggunaan Pagu PNBP BATAN 2017

\begin{tabular}{|c|l|r|r|c|}
\hline No & \multicolumn{1}{|c|}{ Nama Unit Kerja } & \multicolumn{1}{c|}{ Pagu } & Realisasi & \% \\
\hline 1. & PAIR & 2.716 .340 .000 & 2.326 .217 .429 & 85,64 \\
\hline 2. & PTBGN & 642.202 .000 & 37.778 .600 & 5,88 \\
\hline 3. & KANPUS & 0 & 0 & 0 \\
\hline 4. & PSTNT & 437.221 .000 & 330.821 .950 & 75,66 \\
\hline 5. & PSTA & 146.595 .000 & 104.135 .600 & 71,04 \\
\hline 6 & PTKMR & 6.494 .274 .000 & 6.400 .086 .150 & 98,55 \\
\hline
\end{tabular}




\begin{tabular}{|c|l|r|r|c|}
\hline 7. & PPIKSN & 272.250 .000 & 182.910 .000 & 67,18 \\
\hline 8. & PUSDIKLAT & 4.081 .376 .000 & 3.312 .815 .409 & 81,17 \\
\hline 9. & PRSG & 3.070 .445 .000 & 2.165 .606 .157 & 70,53 \\
\hline 10. & PTBBN & 571.327 .000 & 406.607 .093 & 71,17 \\
\hline 11. & PSTBM & 251.731 .000 & 250.824 .500 & 99,64 \\
\hline 12. & PRFN & 74.475 .000 & 0 & 0 \\
\hline 13. & PTRR & 264.000 .000 & 215.299 .899 & 81,55 \\
\hline 14. & PTLR & 1.356 .598 .000 & 309.770 .250 & 22,83 \\
\hline 15. & PTRKN & 0 & 0 & 0 \\
\hline 16. & STTN & 0 & 0 & 0 \\
\hline 17. & PKSEN & 0 & 0 & 0 \\
\hline 18. & INSPEKTORAT & 0.948 .265 .000 & 2.364 .833 .309 & 0 \\
\hline 19. & PDK & 198.0000 .000 & 111.153 .000 & 56,14 \\
\hline 20. & PSMN & $\mathbf{2 3 . 5 2 5 . 0 9 9 . 0 0 0}$ & $\mathbf{1 8 . 5 1 8 . 8 5 9 . 3 4 6}$ & - \\
\hline
\end{tabular}

Sumber Data : Laporan PNBP BATAN Tahun 2017

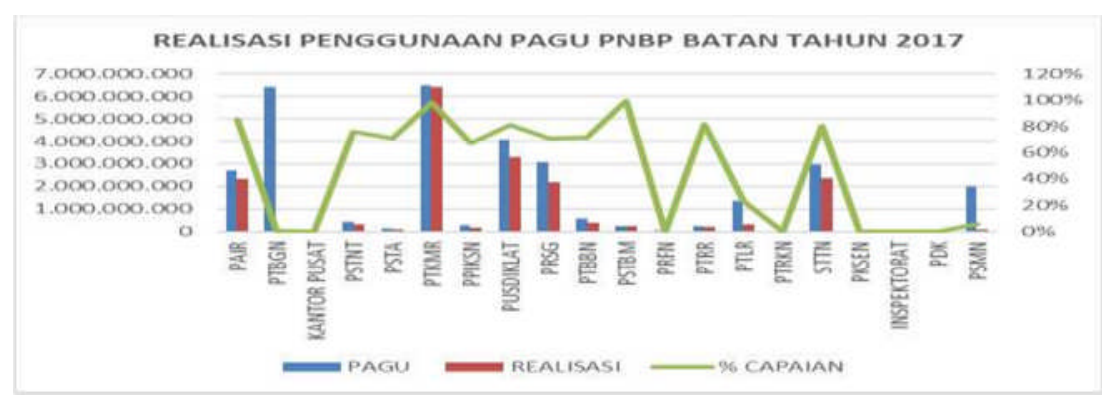

Gambar Grafik 3. Realisasi Penggunaan Pagu PNBP BATAN 2017

Hasil analisis menunjukkan bahwa realisasi penggunaan sebesar $78,72 \%$ atau Rp18.518.859.346,00 dari pagu Rp23.525.099.000,00. Jika dibandingkan dengan realisasi penggunaan PNBP BATAN pada 2016 sebesar 85,99\%, realisasi PNBP pada 2017 juga menurun. Unit kerja yang memiliki penggunaan PNBP terbesar adalah PSTBM sebesar Rp250.824.500,00 (99,64\%) dengan pagu anggaran sebesar Rp251.731.000,00. Penggunaan PNBP terkecil adalah PTBGN sebesar Rp37.778.600,00 (5,88\%) dengan pagu anggaran sebesar Rp642.200.000,00. Hal ini disebabkan oleh kenyataan bahwa tidak banyak biaya operasional dari PNBP yang digunakan untuk kegiatan teknis dan penggunaan anggaran lebih merupakan beban administrasi.

\section{Analisis Jenis dan Tarif Layanan PNBP}

Jenis dan tarif 17 layanan PNBP yang ada di 16 unit kerja di BATAN. Masingmasing unt kerja memberikan kontribusi jumlah dan nilai layanan PNBP yang berbedabeda sesuai dengan kapasitasnya. Secara rinci,dapat dilihat pada tabel dan grafik berikut: 
Tabel. 3. Layanan Jasa PNBP BATAN

\begin{tabular}{|c|l|c|}
\hline No. & \multicolumn{1}{|c|}{ Layanan Jasa PNBP BATAN } & $\begin{array}{c}\text { Jenis } \\
\text { Layanan }\end{array}$ \\
\hline 1. & Jasa Kalibrasi & 13 \\
\hline 2. & Jasa Sertifikasi & 4 \\
\hline 3. & Jasa Analisis Perorangan dan Daerah Kerja & 9 \\
\hline 4. & Jasa Iradiasi & 8 \\
\hline 5. & Jasa Pengelolaan Limbah Radioaktif & 9 \\
\hline 6. & Jasa Eksplorasi Bahan Galian dengan Teknologi Nuklir & 7 \\
\hline 7. & Jasa Pengerjaan dan Uji Mekanik & 15 \\
\hline 8. & Jasa Penyiapan Sampel dan Analisis & 21 \\
\hline 9. & Jasa Konsultasi & 10 \\
\hline 10. & Jasa Pelayanan Teknis Uji Tidak Merusak & 13 \\
\hline 11. & Jasa Keahlian Ketenaganukliran & 3 \\
\hline 12. & Penjualan Produk Teknologi Nuklir & 46 \\
\hline 13. & Jasa Pendidikan dan Pelatihan & 5 \\
\hline 14. & Jasa Sewa Pelatihan Teknologi Nuklir & 9 \\
\hline 15 & Jasa Pendukung Pelaksanaan Tugas dan Fungsi BATAN & 1 \\
\hline
\end{tabular}

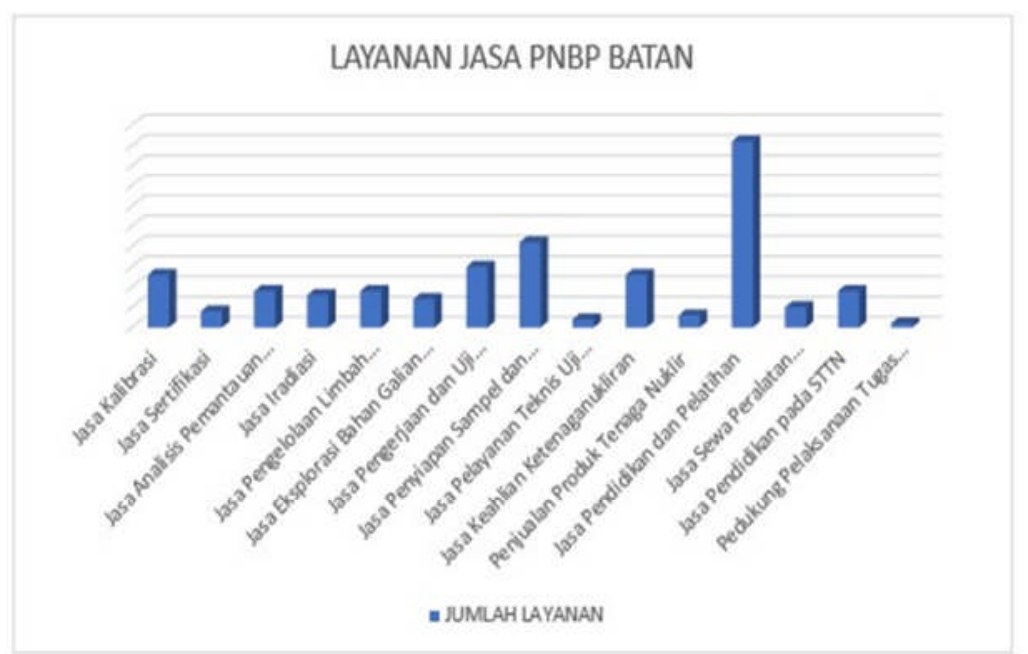

Gambar Grafik 4. Layanan Jasa PNBP BATAN

Hasil analisis pada tabel 3. dan grafik 3. Jenis Penerimaan Negara Bukan Pajak yang berlaku pada Badan Tenaga Nuklir Nasional terdiri 18 layanan PNBP berdasarkan Peraturan Pemerintah Republik Indonensia Nomor 8 Tahun 2019 menunjukkan bahwa layanan Produk Teknologi Nuklir paling banyak jenis layanannya sebanyak 46 layanan. Sedangkan layanan Jasa Pendukung Pelaksanaan Tugas dan Fungsi BATAN paling sedikit jumlah layanannya yaitu 1 layanan. Hal tersebut menunjukkan bahwa layanan Produk Teknologi Nuklir sangat banyak dibutuhkan dan diminati oleh masyarakat. 


\section{KESIMPULAN DAN SARAN}

\section{Kesimpulan}

Pengelolaan PNBP di BATAN pada tahun 2017 terdapat 2 unit kerja dengan realisasi penerimaan melampaui target. Total realisasi penerimaan diatas $90 \%$. Dibanding dengan tahun 2016 realisasi penerimaan mengalami penurunan sekitar 12,03\%. Dari sisi penggunaan, PSTBM memiliki realisasi penggunaan PNBP terbesar sebesar 99,64\%, dan terkecil adalah PTBGN dengan realisasi 5,88\%. Realisasi penggunaan PNBP di BATAN pada tahun 2017 sebesar 78,72\%, mengalami penurunan dibanding tahun 2016 dengan realisasi penggunaan $85,99 \%$.

\section{Saran}

Realisasi pendapatan dan penggunaan PNBP BATAN masih bisa ditingkatkan. Unit kerja peneglolaan PNBP seperti PTBGN, PRSG, PRFN dan PTLR dapat mendekati pelanggan potensial melalui pertemuan pelanggan. Pengelolaan PNBP oleh unit kerja, khususnya PTBGN, direncanakan lebih baik sehingga realisasi penggunaannya meningkat, sehingga nilai PNBP dapat bermanfaat untuk meningkatkan kemampuan dan kualitas layanan.

\section{REFERENSI}

Dinarjito, Agung. (2017). Pengelolaan Penerimaan Negara Bukan Pajak: Study Kasus Pada Kantor Pertanahan Wilayah Provinsi Daerah Istimewa Yogyakarta. Jurnal Manajemen Keuangan 1: 57-69.

Iriviranty, Afrisya.(2014). Analisis Budaya Organisasi Dan Budaya Keselamatan Pasien Sebagai Langkah Pengembangan Keselamatan Pasien Di RSIA Budi Kemuliaan Tahun 2014. Jurnal administrasi Rumah sakit 1(3): 196-206.

Peraturan Pemeritah Republik Indonesia Nomor 29 Tahun 2011. (2011). Jenis Dan Tarif Atas Jenis Penerimaan Negara Bukan Pajak Yang Berlaku Pada Badan Tenaga Nuklir Nasinal. : 1-38.

Rima P.A Walelang. (2017). Analysis of the Administration Effectiveness of Non Tax Revenue on State. 5(2): 2647-55.

Tahun, Peraturan Pemerintah Republik Indonesia Nomor 8. (2019). Jenis Dan Tarif Atas Jenis PNBP Yang Berlaku Pada BATAN.

Undang-undang Nomor 20 Tahun 1997. 1997. Penerimaan Negara Bukan Pajak. 21(3): 295-316. 